\title{
PENGARUH PEMAPARAN MEDAN MAGNET 0,2 mT PADA MEDIA YANG MENGANDUNG LOGAM (Al, Pb, Cd, dan Cu) TERHADAP Bacillus sp. DALAM MENGHASILKAN PROTEASE
}

\author{
[The Influence of 0.2 Mt Magnetic Field Exposure on Media Containing Metal ( $\mathrm{Al}, \mathrm{Pb}, \mathrm{Cd}$, \\ and $\mathrm{Cu}$ ) on Bacillus sp. in the Producing of Protease]
}

\author{
Sumardi*夰, Rochmah Agustrina, Bambang Irawan dan Shofia Rodiah \\ Jurusan Biologi FMIPA Universitas Lampung \\ Jl. Soemantri Brojonegoro No. 1, Gedung Meneng, Bandar Lampung, 35145, Indonesia \\ email: sumardibio@yahoo.co.id
}

\section{ABSTRACT}

This study aimed to determine the effect of $0.2 \mathrm{mT}$ magnetic field exposure on metals $(\mathrm{Al}, \mathrm{Pb}, \mathrm{Cd}$, and $\mathrm{Cu}$ ) containing media, to proteolytic index of Bacillus sp., protease activity and cell morphology of Bacillus sp. This study consisted of three stages. The first stage was a proteolytic test on solid media containing milk. The second stage was the production of protease enzymes in liquid media. The third stage was Scanning Electron Microscopy (SEM) analysis on a culture treatment known as protease enzyme activity. The results showed that the largest proteolytic index on $\mathrm{CuCl}_{2}$ metal ion content of magnetic $0.2 \mathrm{mT}$ magnetic field for 10 minutes increased the value of the largest proteolytic index was 4.33 . While in the ion solution containing $\mathrm{CdCl}_{2}$, Bacillus sp. culture did not grow. In the production of enzymes in the liquid medium, the highest enzyme activity $(0.140 \mathrm{U} / \mathrm{ml})$ was produced on a medium containing $\mathrm{AlCl}_{3}$ and exposed to magnetic fields. The SEM analysis also proved that the supplementation of $\mathrm{AlCl}_{3}$ increased cell length by 2.38 and 2.78 times longer than control without magnetic field and for magnet field, respectivelly.

Key words: Bacillus sp., protease, magnetic field, metal ion

\section{ABSTRAK}

Penelitian ini bertujuan untuk mengetahui pengaruh pemaparan medan magnet $0,2 \mathrm{mT}$ pada media yang mengandung logam $\mathrm{Al}, \mathrm{Pb}, \mathrm{Cd}$, dan $\mathrm{Cu}$ terhadap nilai indeks proteolitik Bacillus sp., aktivitas protease Bacillus sp. dan morfologi sel Bacillus sp. Penelitian ini terdiri tiga tahap. Tahap pertama yaitu uji proteolitik pada media padat yang mengandung susu. Tahap kedua yaitu produksi enzim protease pada media cair. Tahap ketiga yaitu analisa Scanning Electron Microscopy (SEM) pada perlakuan kultur yang diketahui aktivitas enzim proteasenya. Hasil penelitian menunjukkan bahwa indeks proteolitik terbesar pada larutan ion logam $\mathrm{CuCl}_{2}$ yang paparan medan magnet $0.2 \mathrm{mT}$ selama 10 menit meningkatkan nilai indeks proteolitik terbesar yaitu 4,33. Sedang pada larutan ion yang mengandung $\mathrm{CdCl}_{2}$, kulturBacillus sp. tidak tumbuh. Pada produksi enzim di medium cair, aktivitas enzim tertinggi $(0,140 \mathrm{U} / \mathrm{ml})$ dihasilkan pada medium yang mengandung larutan ion $\mathrm{AlCl}_{3}$ yang dipapar medan magnet. Hasil analisis SEM juga membuktikan bahwa pemberian logam $\mathrm{AlCl}_{3}$ meningkatkan panjang sel hingga 2,38 kali dibandingkan kontrol tanpa medan magnet dan 2,78 kali untuk yang diberi medan manget.

Kata kunci: Bacillus sp., Protease, Medan magnet, Ion logam

\section{PENDAHULUAN}

Protease termasuk enzim golongan hidrolase yang berperan dalam reaksi pemecah protein. Enzim ini dapat menghidrolisis ikatan peptida dan protein menjadi oligopeptida dan asam amino. Protease dapat diproduksi oleh Bacillus dan berfungsi diluar sel. Beberapa enzim protease bakteri Bacillus berhasil diisolasi dari lingkungan seperti tanah rawa (Baehaki et al., 2011), tanah gambut (Mahdiyah, 2015), ampas tahu (Badriyah dan Ardiyati, 2013), dan lain-lain. Produksi enzim dapat ditingkatkan dengan cara mengoptimalkan faktor-faktor lingkungan seperti sumber karbon, sumber nitrogen, dan komposisi medium (Erika et al., 2016).

Faktor lingkungan lain yang akhir-akhir ini banyak diteliti adalah medan magnet. Pemaparan medan magnet pada substrat media dapat mempengaruhi karakteristik pertumbuhan dan jumlah sel bakteri (Hernawati et al., 2016). Selain itu, diketahui juga bahwa kandungan ion logam dapat mempengaruhi aktivitas dan produksi enzim pada mikroba (Sumardi et al., 2018b). Logam-logam yang diduga dapat mempengaruhi aktivitas Bacillus sp. antara lain $\mathrm{Al}, \mathrm{Pb}, \mathrm{Cd}$, dan $\mathrm{Cu}$. Logam-logam tersebut mempunyai sifat paramagnetik dan diamagnetik, yang apabila dikenai medan magnet dapat berpengaruh terhadap produksi protease. Potensi faktor ion logam dan medan magnet ini sangat berperan dalam peningkatan kualitas plasma nutfah di Indonesia. Dengan memperhatikan hal tersebut, maka penelitian pengaruh paparan medan magnet $0,2 \mathrm{mT}$ pada media yang mengandung logam 
$\mathrm{Al}, \mathrm{Pb}, \mathrm{Cd}$, dan $\mathrm{Cu}$ terhadap nilai indeks proteolitik Bacillus sp., aktivitas protease Bacillus sp. dan morfologi sel Bacillus sp. sangat diperlukan. Pemilihan paparan medan magnet $0,2 \mathrm{mT}$ menjadi faktor penting karena paparan tersebut menyebabkan pertumbuhan koloni sangat pesat dibandingkan dengan paparan yang lain (Sumardi et al., 2019). Dengan demikian maka enzim-enzim yang terlibat dalam pertumbuhan tersebut bekerja secara maksimal.

\section{BAHAN DAN CARA KERJA}

Penelitian ini dilaksanakan pada 1 Juni 2017 30 Agustus 2017 di Laboratorium Mikrobiologi, Laboratorium Botani FMIPA Unila, dan analisa SEM bakteri dilakukan di Balai Besar Penelitian dan Pengembangan Pascapanen Pertanian, Bogor.

Alat yang digunakan dalam penelitian ini antara lain: spectrophotometer model UV-1800 240V, no katalog 206-25400-38 no seri A11455008999 Shimadzu (Jepang) untuk mengukur aktivitas enzim protease; inkubator untuk menginkubasi bakteri pada suhu yang terkontrol; dan laminar airflow untuk perlakuan yang memerlukan kondisi aseptik, termasuk inokulasi bakteri; kumparan medan magnet sebesar $0.2 \mathrm{mT}$ untuk pemberian treatment pada Bacillus sp.

Bahan yang digunakan dalam penelitian ini antara lain: isolat Bacillus sp. yang diperoleh dari koleksi biakan di Laboratorium Mikrobiologi FMIPA Unila. Media untuk kultur yaitu media Mandels (Mandels dan Reese, 1956) yang dimodifikasi $(\mathrm{NaCl} 0,2 \%$, yeast extract 0,35\%, $\mathrm{KH}_{2} \mathrm{PO}_{4} 0,245 \%, \mathrm{MgSO}_{4} 0,035 \%,\left(\mathrm{NH}_{4}\right)_{2} \mathrm{SO}_{4} 0,17$ $\%$, skim milk $0,5 \%$ dan agar $1,5 \%$ ).

Tahap pertama penelitian dilakukan uji penentuan indeks proteolitik (IP) yang terbentuk di sekitar koloni bakteri yang tumbuh pada media padat Mandels yang dimodifikasi. Perlakuan merupakan kombinasi larutan ion logam dan paparan medan magnet. Larutan ion logam yang digunakan adalah $\mathrm{AlCl}_{3}, \mathrm{PbCl}_{2}, \mathrm{CdCl}_{2}$ dan $\mathrm{CuCl}_{2}$. Paparan medan magnet yang digunakan adalah 0,2 $\mathrm{mT}$ selama 10 menit ke larutan ion logam.

Kombinasi perlakuan adalah sebagai berikut

Perlakuan 1 (M-0). Perlakuan M-0 merupakan perlakuan kontrol dengan menggunakan media padat Mandels yang dimodifikasi tidak diberi paparan medan magnet dan tidak diberi larutan ion logam.

Perlakuan 2 (M-1). Perlakuan M-1 merupakan perlakuan dengan menggunakan media padat Mandels yang dimodifikasi dan diberi larutan ion logam $\mathrm{AlCl}_{3}$. Larutan ion logam $\mathrm{AlCl}_{3}$ tidak dipapar medan magnet.

Perlakuan 3 (M-2). Perlakuan M-2 merupakan perlakuan dengan menggunakan media padat Mandels yang dimodifikasi dan diberi larutan ion logam $\mathrm{AlCl}_{3}$. Larutan ion logam $\mathrm{AlCl}_{3}$ dipapar medan magnet $0,2 \mathrm{mT}$ selama 10 menit.

Perlakuan 4 (M-3). Perlakuan M-3 merupakan perlakuan dengan menggunakan media padat Mandels yang dimodifikasi dan diberi larutan ion logam $\mathrm{PbCl}_{2}$. Larutan ion logam $\mathrm{PbCl}_{2}$ tidak dipapar medan magnet.

Perlakuan 5 (M-4). Perlakuan M-4 merupakan perlakuan dengan menggunakan media padat Mandels yang dimodifikasi dan diberi larutan ion logam $\mathrm{PbCl}_{2}$. Larutan ion logam $\mathrm{PbCl}_{2}$ dipapar medan magnet $0.2 \mathrm{mT}$ selama 10 menit.

Perlakuan 6 (M-5). Perlakuan M-5 merupakan perlakuan dengan menggunakan media padat Mandels yang dimodifikasi dan diberi larutan ion logam $\mathrm{CdCl}_{2}$. Larutan ion logam $\mathrm{CdCl}_{2}$ tidak dipapar medan magnet.

Perlakuan 7 (M-6). Perlakuan M-6 merupakan perlakuan dengan menggunakan media padat Mandels yang dimodifikasi dan diberi larutan ion logam $\mathrm{CdCl}_{2}$. Larutan ion logam $\mathrm{CdCl}_{2}$ dipapar medan magnet $0.2 \mathrm{mT}$ selama 10 menit.

Perlakuan 8 (M-7). Perlakuan M-7 merupakan perlakuan dengan menggunakan media padat Mandels yang dimodi-fikasi dan diberi larutan ion logam $\mathrm{CuCl}_{2}$. Larutan ion logam $\mathrm{CuCl}_{2}$ tidak dipapar medan magnet.

Perlakuan 9 (M-8). Perlakuan M-8 merupakan perlakuan dengan menggunakan media padat Mandels yang dimodifi-kasi dan diberi larutan ion logam $\mathrm{CuCl}_{2}$. Larutan ion logam $\mathrm{CuCl}_{2}$ dipapar medan magnet $0.2 \mathrm{mT}$ selama 10 menit.

Pengamatan keberadaan zona jernih yang terbentuk di sekitar koloni bakteri dilakukan setelah 
kultur bakteri diinkubasi selama 18 jam dalam inkubator pada suhu $37^{\circ} \mathrm{C}$. Terbentuknya zona jernih menunjukkan adanya aktivitas enzim protease. Nilai IP isolat $\geq 3$ menunjukkan bahwa isolat memiliki potensi besar dan maksimal sebagai sumber protease (Said dan Likadja, 2012).

Koloni bakteri dan zona bening yang terbentuk di sekitar koloni bakteri, diukur diameternya dan ditentukan Indeks Proteolitik (IP):

Indeks proteolitik dapat dihitung menggunakan rumus:

$\mathrm{IP}=\frac{\mathrm{B}}{\mathrm{A}}$

Keterangan :

IP : Indeks Proteolitik

A : Diameter Koloni

B : Diameter Zona Jernih (Sumardi et al., 2010).

Tahap kedua penelitian yaitu produksi enzim protease pada media cair Mandels yang dimodifikasi dan diberi logam $\mathrm{AlCl}_{3}, \mathrm{PbCl}_{2}, \mathrm{CuCl}_{2}$ dengan masing-masing konsentrasi yang digunakan adalah 0 ppm dan $30 \mathrm{ppm}$. Media yang digunakan mirip seperti pada uji penentuan indeks proteolitik, namun tidak menggunakan substrat agar. Sedang perlakuan yang digunakan juga mirip dengan dengan uji penentuan indeks namun tidak menggunakan larutan ion logam $\mathrm{CdCl}_{2}$ karena di media tersebut larutan bakteri tidak tumbuh.

Produksi enzim dilakukan sesuai dengan perlakuan masing-masing pada media tanpa adanya penambahan agar. Produksi enzim dilakukan dengan menginokulasikan $5 \mathrm{ml}$ starter Bacillus sp. yang telah diinkubasi semalam pada $45 \mathrm{ml}$ media cair Mandels yang dimodifikasi dalam Erlenmeyer $250 \mathrm{ml}$ dengan perlakuan sama seperti pada uji proteolitik. Semua perlakuan kultur diinkubasi pada inkubator goyang dengan kecepatan $120 \mathrm{rpm}$ pada suhu $40{ }^{\circ} \mathrm{C}$ selama 24 jam. Ekstrak kasar enzim protease yang diperoleh kemudian disentrifugasi dengan kecepatan $6.700 \mathrm{~g}$ selama 15 menit pada suhu $4{ }^{\circ} \mathrm{C}$.

Enzim kasar tersebut selanjutnya diuji aktivitas proteasenya. Sebanyak $0.1 \mathrm{ml}$ sampel protease ekstrak kasar ditambahkan pada $0.5 \mathrm{ml}$ substrat kasein dalam bufer fosfat $\mathrm{pH}$ 7. Campuran kemudian diinkubasi pada suhu $40{ }^{\circ} \mathrm{C}$ selama 10 menit. Reaksi enzim dihentikan dengan $0,5 \mathrm{ml}$ asam trikloroasetat (TCA) 0,1 M. Campuran kemudian diinkubasi pada suhu $40{ }^{\circ} \mathrm{C}$ selama 10 menit dan disentrifugasi pada kecepatan $6.700 \mathrm{~g}$ dan suhu $4{ }^{\circ} \mathrm{C}$ selama 10 menit. Supernatan hasil sentrifugasi diambil sebanyak 0,375 ml. Sebanyak $1,25 \mathrm{ml}$ larutan $\mathrm{Na}_{2} \mathrm{CO}_{3} \quad 0,4 \mathrm{M}$ dan $0,25 \mathrm{ml}$ pereaksi Folin ditambahkan ke dalam supernatan tersebut, kemudian diinkubasi pada suhu $37{ }^{\circ} \mathrm{C}$ selama 20 menit (Bergmeyer dan Grassl, 1983). Pengamatan dilakukan dengan mengukur optical density (OD) pada $\lambda=578 \mathrm{~nm}$. Perhitungan untuk nilai blanko dilakukan dengan cara yang sama, dimana sampel protease diganti dengan aquades. Sedangkan perhitungan nilai standar dilakukan dengan mengganti sampel protease dengan tirosin $5 \mathrm{mM}$.

Aktivitas protease dihitung dalam satuan PU (Protease Unit) per ml ekstrak enzim. Satu unit aktivitas enzim protease didefinisikan sebagai jumlah enzim yang dapat menghasilkan satu $\mu$ mol tirosin per menit pada kondisi pengukuran diukur menggunakan rumus sebagai berikut:

$$
\mathrm{PU}=\frac{\mathrm{A}_{\mathrm{sp}}-\mathrm{A}_{\mathrm{bl}}}{\mathrm{A}_{\mathrm{st}}-\mathrm{A}_{\mathrm{bl}}} \times \frac{1}{\mathrm{~T}}
$$

Keterangan:

PU : Unit Aktivitas Protease (Unit $/ \mathrm{ml}$ )

$A_{\text {sp }} \quad$ : Nilai Absorbansi Sampel

$A_{\text {st }} \quad$ : Nilai Absorbansi Strandar

$A_{b l} \quad$ Nilai Absorbansi Blanko

$\mathrm{T} \quad$ : Waktu

\section{Morfologi Bacillus sp. dengan pemeriksaan mikroskope electron (SEM: Scanning Electron Microscope)}

Analisa SEM merk ZEISS tipe EVOMA10 (Jerman) dilakukan di Balai Besar Penelitian dan Pengembangan Pascapanen Pertanian, Bogor. Sampel bakteri yang telah diinkubasi semalam disiapkan dalam bentuk serbuk kering menggunakan freeze dryer. Sampel ditaburkan setipis mungkin pada specimen stub yang sudah dilapisi dengan double tape carbon. Tahapan berikutnya adalah pelapisan menggunakan sputter coater yaitu proses pelapisan pada permukaan sampel yang berfungsi untuk memperkuat sifat konduktif/daya hantar listrik. Coating dilakukan dengan menggunakan material 
emas $(A u)$ pada kuat arus $20 \mathrm{~mA}$ selama 60 detik. Sampel yang sudah dilapisi emas selanjutnya dipasang dalam specimen holder untuk dianalisa SEM (Singh et al., 2017 dan Zeiss, 2019).

\section{HASIL}

Aktivitas proteolitik bacillus sp.

Aktivitas proteolitik isolat Bacillus sp. yang di tandai dengan terbentuknya zona jernih di sekeliling koloni bakteri, menunjukkan bahwa isolat tersebut berpotensi menghasilkan protease (Gambar 1).

Aktivitas hidrolisis adalah fenomena yang menunjukkan adanya kemampuan bakteri proteolitik untuk membentuk zona jernih di sekitar isolat bakteri yang tumbuh dalam media selektif pertumbuhan yang mengandung susu sebagai substrat.

\section{Nilai indeks proteolitik Bacillus sp. pada media padat}

Hasil uji proteolitik dari ke-9 perlakuan menunjukkan terdapat tujuh perlakuan yang menghasilkan isolat yang mempunyai aktivitas proteolitik yang ditandai dengan terbentuknya zona jernih disekeliling koloni bakteri. Aktivitas proteolitik tersebut ditunjukkan pada perlakuan M-0, M-1, M-2, M-3, M- 4, M-7, M-8. Pada perlakuan
M-5 dan M-6 tidak ditemukan adanya aktivitas proteolitik karena koloni bakteri tidak tumbuh (Gambar 2).

Hasil pengukuran nilai IP dari kesembilan perlakuan menunjukkan bahwa perlakuan kontrol (M) menghasilkan rerata nilai IP yaitu 1,43. Rerata nilai IP meningkat setelah pemberian ion-ion logam $\mathrm{Al}, \mathrm{Pb}$ dan $\mathrm{Cu}$ (M-1, M-3, dan M- 7) yaitu 1,63; 2,27; dan 3,7. Rerata nilai IP meningkat dua kali lebih besar setelah ion-ion logam yang digunakan diberi paparan medan magnet 0,2 $\mathrm{mT}$ selama 10 menit sebelum ditambahkan ke dalam media Mandels yang dimodifikasi (M-2, M-4, dan M-8) yaitu 2,3; 2,57; dan 4,33 (Gambar 2).

\section{Aktivitas enzim protease Bacillus sp. pada media cair}

Hasil pengujian aktivitas enzim protease menunjukkan rerata nilai aktivitas protease pada perlakuan kontrol (M-0) yaitu $0.031 \mathrm{U} / \mathrm{ml}$. Nilai aktivitas protease menurun setelah penambahan ion-ion logam $\mathrm{Al}, \mathrm{Pb}$ dan $\mathrm{Cu}$ pada media cair Mandels yang dimodifikasi (M-1, M-3, dan M-7) yaitu $0.016 \mathrm{U} / \mathrm{ml}, 0.023 \mathrm{U} / \mathrm{ml}$, dan $0.030 \mathrm{U} / \mathrm{ml}$. Nilai aktivitas protease meningkat setelah ion-ion logam tersebut dipapar medan magnet yakni: perlakuan M-2, M-4, dan M-8 yaitu $0.140 \mathrm{U} / \mathrm{ml}, 0.083 \mathrm{U} / \mathrm{ml}$, dan $0.065 \mathrm{U} / \mathrm{ml}$ (Gambar 4).

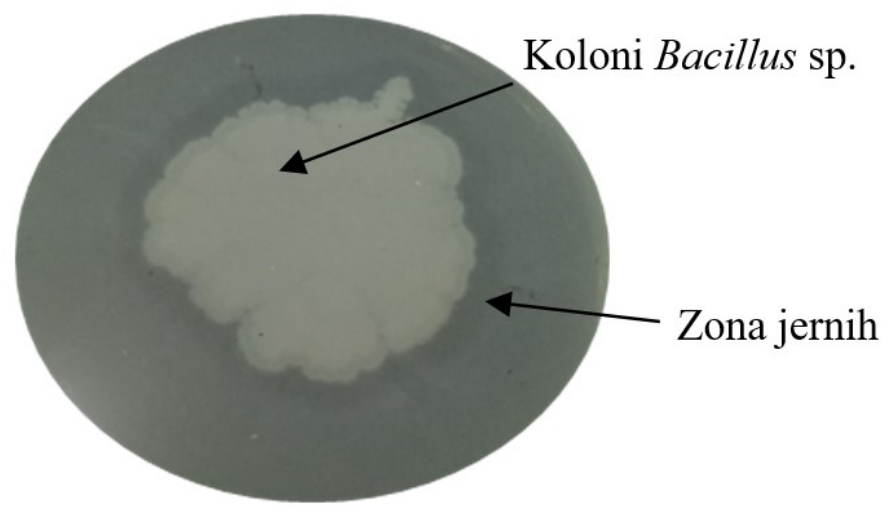

Gambar 1. Zona jernih sebagai indikator aktivitas proteolitik Bacillus sp. (Clear zone as an indicator of proteolytic activity of Bacillus sp.) 

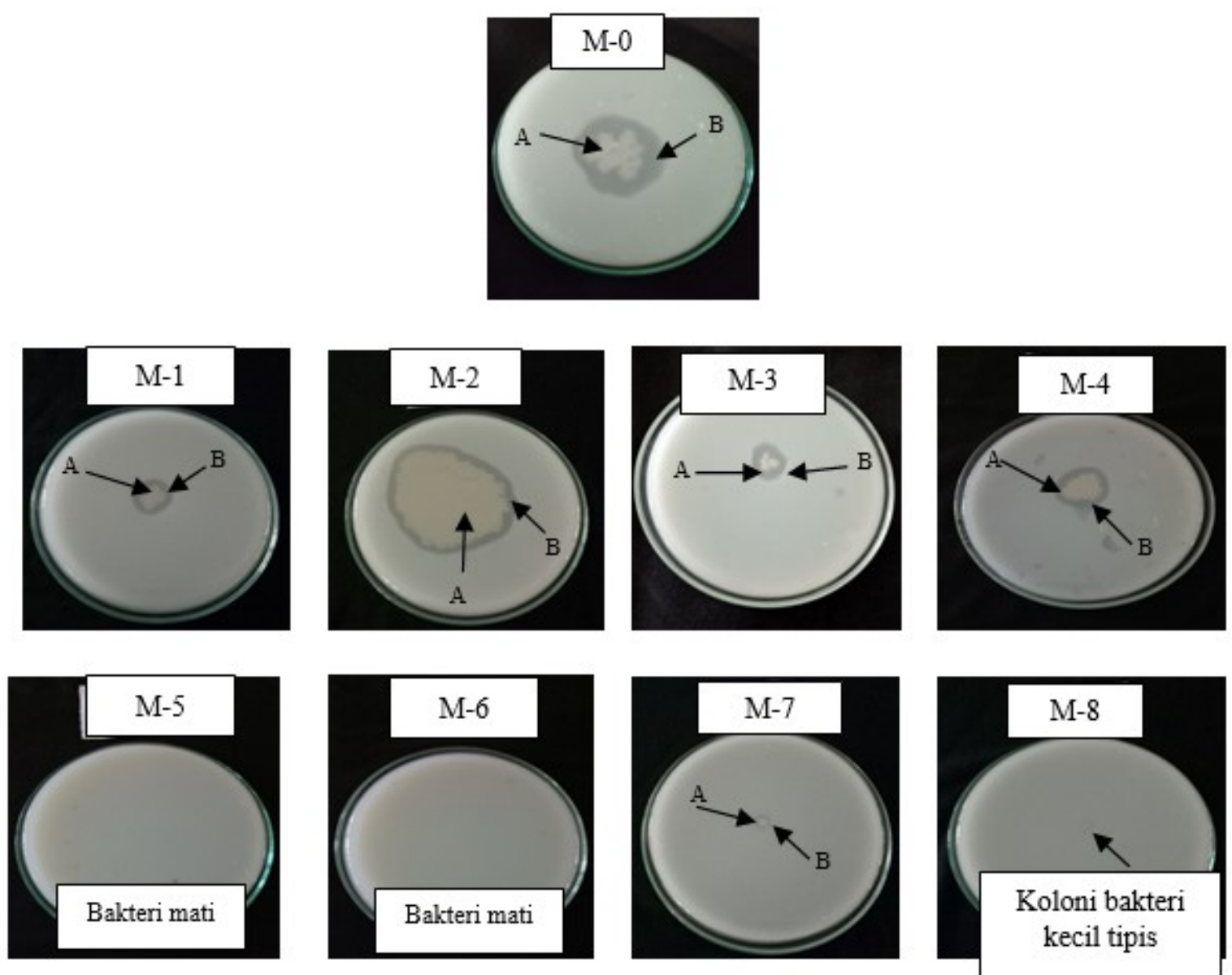

Gambar 2. Koloni Bacillus sp. (A) dan zona jernih (B). [Colony of Bacillus sp. (A) and clear zone (B).]

\section{Morfologi Bacillus sp. akibat paparan medan magnet 0,2 mT dengan pengamatan SEM}

Morfologi sel Bacillus sp. mengalami perubahan akibat pemberian ion logam pada media Mandels yang dimodifikasi. Ion-ion logam yang diberikan ( $\mathrm{Al}, \mathrm{Pb}$, dan $\mathrm{Cu}$ ) baik yang dipapar maupun yang tidak dipapar medan magnet 0,2 $\mathrm{mT}$ sebelum ditambahkan pada media Mandels yang dimodifikasi menyebabkan perubahan pada ukuran sel Bacillus sp. pada fase logaritmik (umur semalam).

Ukuran panjang sel Bacillus sp. pada perlakuan kontrol, yaitu pada media Mandels yang dimodifikasi adalah 1,537 $\mu \mathrm{m}$ (Gambar 5). Ukuran tersebut relatif lebih kecil dibandingkan dengan perlakuan lainnya.

Peningkatan ukuran sel juga disebabkan karena medan magnet mempengaruhi membran sel bakteri, sehingga mempengaruhi morfologi sel bakteri. Pada penelitian ini ukuran panjang sel bakteri meningkat 2,38 kali lebih besar setelah pemberian ion logam Al pada media dan meningkat 2,75 kali lebih besar setelah ion logam Al diberi paparan medan magnet $0,2 \mathrm{mT}$ selama 10 menit (Tabel 1).

Paparan medan magnet pada ion logam $\mathrm{Pb}$ (M-4) meningkatkan ukuran panjang sel menjadi 1,708 $\mu \mathrm{m}$ dari $1,229 \mu \mathrm{m}$ hasil perlakuan 


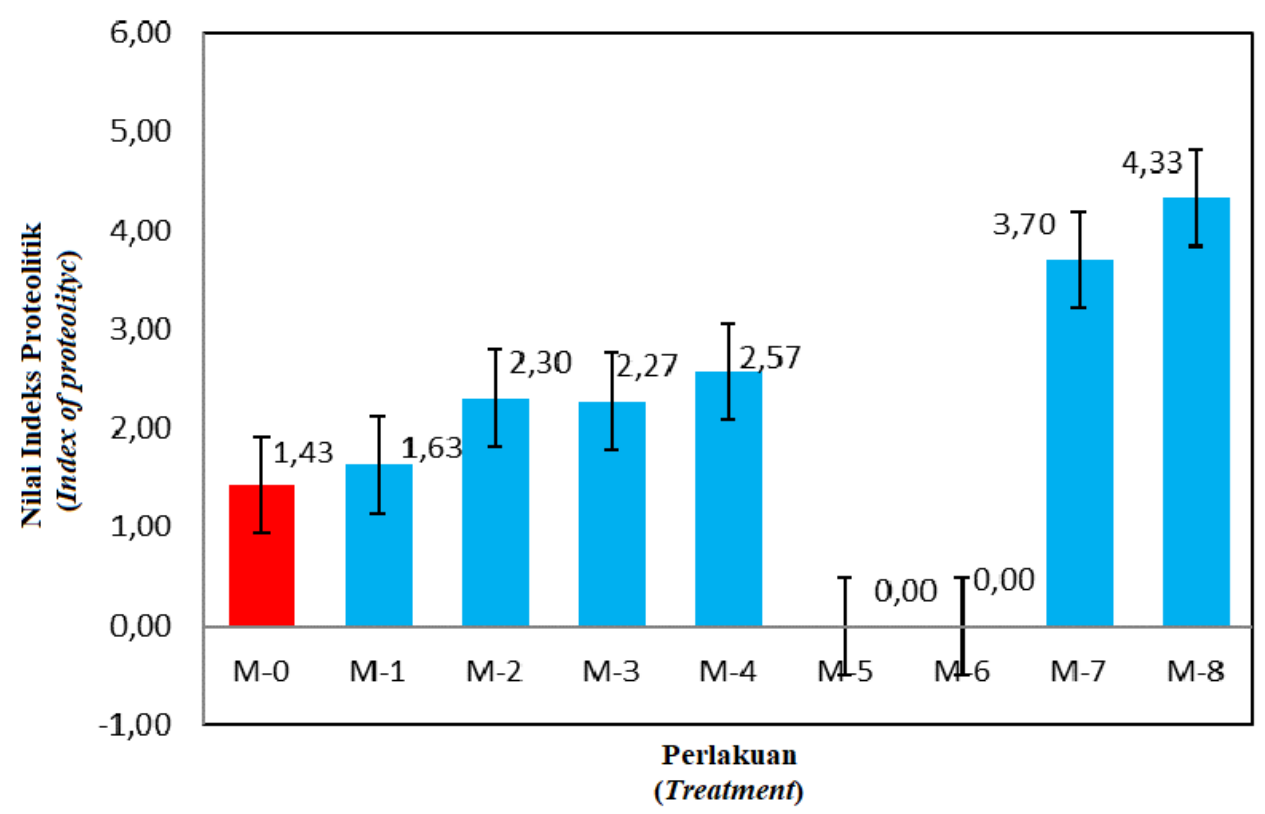

Gambar 3. Rerata Nilai Indeks Proteolitik (IP) Bacillus sp. Bacillus sp. (Average Index of Proteolytic (IP) of Bacillus sp.)

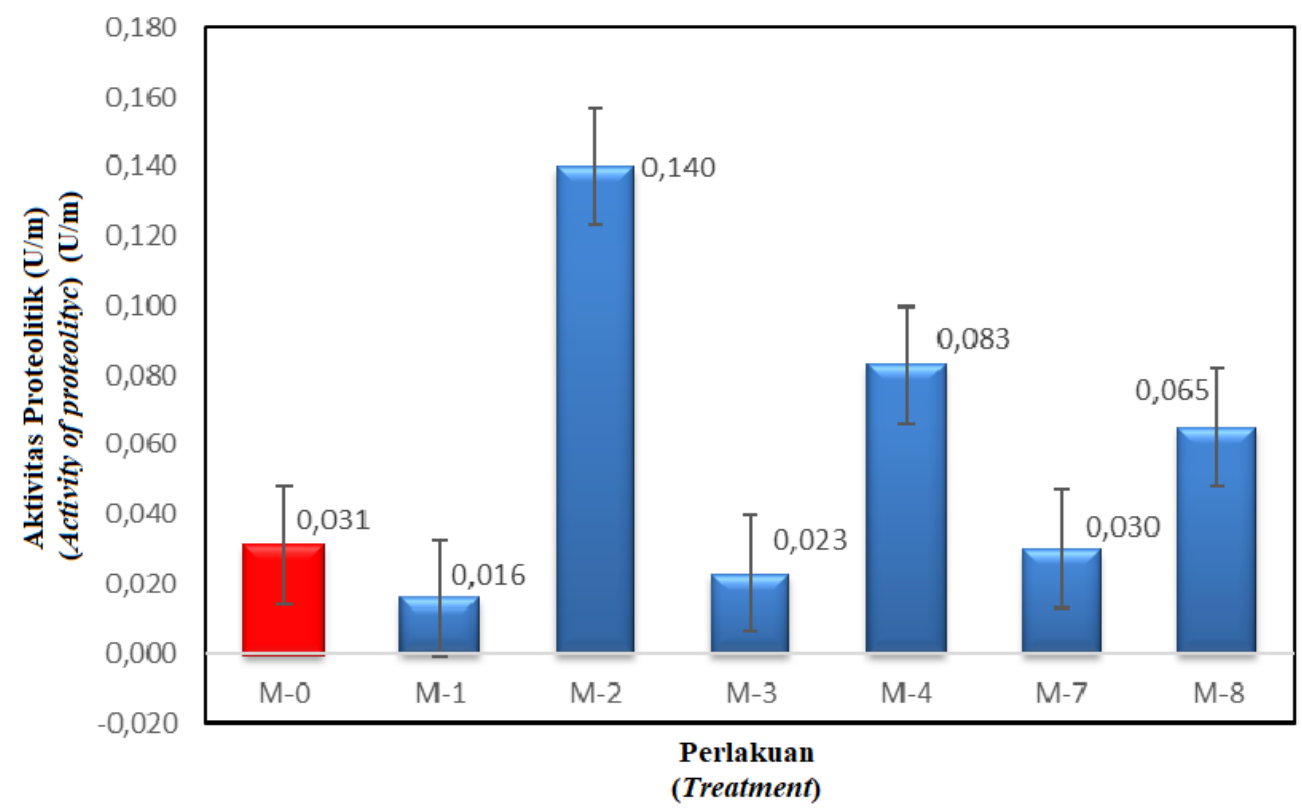

Gambar 4. Nilai Aktivitas Proteolitik Bacillus sp. pada setiap perlakuan. (Proteolytic activity of Bacillus sp. of every treatment.) 


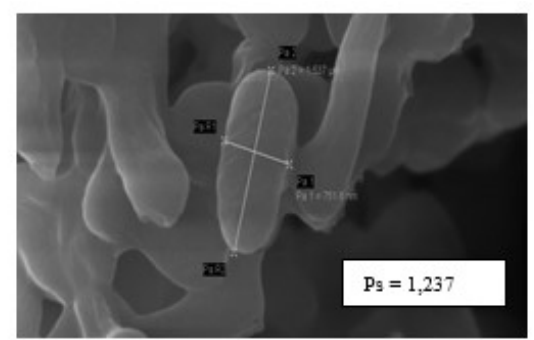

(M-0)

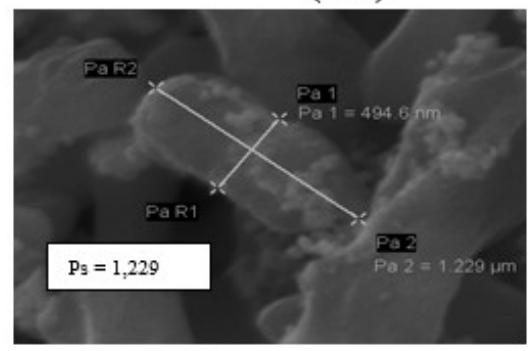

(M-3)

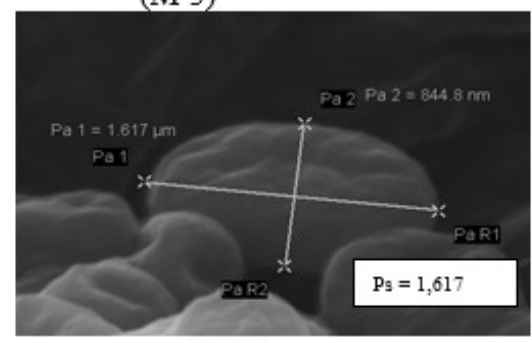

(M-8)

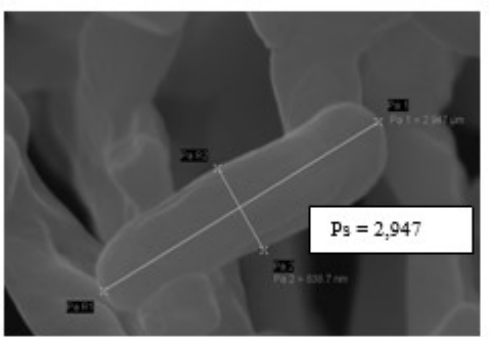

(M-1)

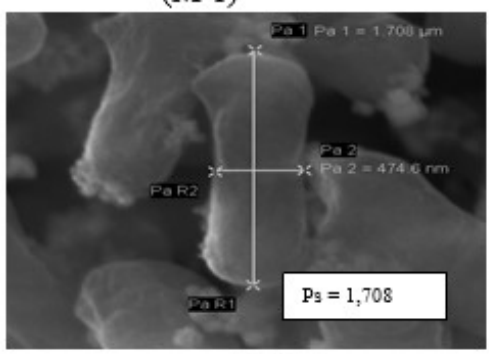

(M-4)

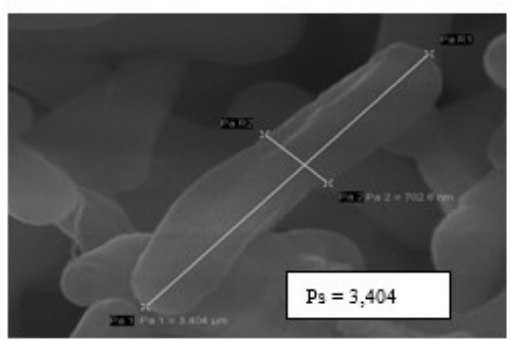

(M-2)

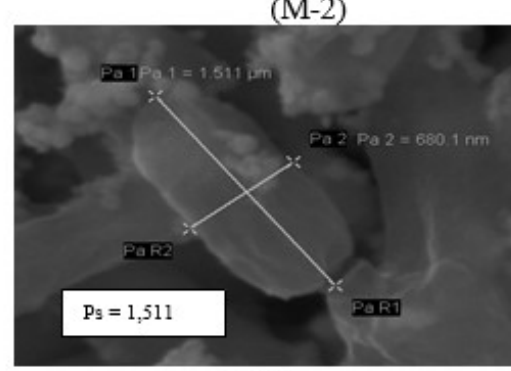

(M-7)

Gambar 5. Morfologi sel Bacillus sp. pada perbesaran 20.000 kali dengan Scaning Microscope Electron (SEM). (Cell morphology of Bacillus sp. was be magnification 20,000 $x$ with scaning mircroscope electron)

penambahan ion $\mathrm{Pb}$ tanpa paparan medan magnet (M-3) (Gambar 5). Penambahan ukuran panjang sel bakteri sebagai akibat penambahan ion logam $\mathrm{Cu}$ yang diberi paparan medan magnet $0,2 \mathrm{mT}$ sebelum ditambahkan pada media juga meningkatkan ukuran panjang sel bakteri. Ukuran panjang sel bakteri dari 1,511 $\mu \mathrm{m}$ (M-7) menjadi 1,617 $\mu \mathrm{m}(\mathrm{M}-8)$.

\section{PEMBAHASAN}

Aktivitas enzim menghidrolis substrat protein susu ditunjukkan dengan kemampuan bakteri tumbuh menghasilkan zona jernih di sekitar koloninya. Menurut Rosliana (2009), susu merupakan media yang sesuai untuk pertumbuhan bakteri proteolitik karena mengandung banyak kasein. Kasein merupakan protein susu yang terdiri dari fosfoprotein yang berikatan dengan kalsium membentuk garam kalsium yang disebut kalsium kalsenat. Kalsium kalsenat berukuran sangat besar dan tidak larut dalam air membentuk koloid berwarna putih dalam kultur media padat (Soeka dan Sulistiani, 2014).

Zona jernih yang terbentuk di sekitar koloni bakteri menandakan hilangnya partikel kasein di media susu skim. Eksresi enzim proteolitik ekstraseluler bakteri ke media menyebabkan kasein dalam media terhidrolisis menjadi peptida-peptida dan asam amino yang larut. Enzim ekstraseluler Bacillus sp. sangat efisien dalam mengurai berbagai senyawa karbohidrat, lipid, dan protein rantai panjang menjadi unit-unit rantai pendek atau 
Tabel 1. Panjang Sel Bacillus sp. perbesaran 20.000x dengan SEM [Length of Bacillus sp. was be magnification 20,000x with scaning mircroscope electron (SEM).]

\begin{tabular}{cccc}
\hline No & $\begin{array}{c}\text { Perlakuan } \\
(\text { Treatment })\end{array}$ & $\begin{array}{c}\text { Panjang Sel }(\mu \mathrm{m}) \\
(\text { Cell length })(\mu \mathrm{m})\end{array}$ & $\begin{array}{c}\text { Peningkatan Ukuran Panjang } \\
(\text { Increasing length })\end{array}$ \\
\hline 1 & M-0 & 1.237 & 1 \\
2 & M-1 & 2.947 & 2,38 \\
3 & M-2 & 3.404 & 2,75 \\
4 & M-3 & 1.229 & 0,99 \\
5 & M-4 & 1.708 & 1,38 \\
6 & M-7 & 1.511 & 1,22 \\
7 & M-8 & 1.617 & 1,30 \\
\hline
\end{tabular}

senyawa-senyawa yang lebih sederhana (Yusufa et al., 2012). Selanjutnya, paparan medan magnet $0,2 \mathrm{mT}$ selama 10 menit pada ion-ion logam di dalam komposisi media Mandels yang dimodifikasi ternyata meningkatkan rerata nilai indeks proteolitik dibandingkan dengan yang tidak diberi paparan medan magnet. Ion-ion logam $\mathrm{Al}, \mathrm{Pb}$, dan $\mathrm{Cu}$ memiliki sifat kemagnetan paramagnetik pada ion logam $\mathrm{Al}$ dan diamagnetik pada ion logam $\mathrm{Pb}$ dan $\mathrm{Cu}$. Ion logam $\mathrm{Al}$ pada awalnya memiliki arah medan magnet yang acak karena belum termagnetisasi.

Hasil pengamatan pada perlakuan M-5 dan M-6 tidak menunjukkan adanya aktivitas proteolitik. Hal tersebut membuktikan bahwa dalam penelitian ini, ion logam $\mathrm{Cd}$ menghambat pertumbuhan Bacillus sp. Dengan demikian maka tidak ada aktivitas proteolitik pada media pertumbuhan (Gambar 3). Jonak et al. (2004) mengatakan bahwa logam $\mathrm{Cd}$ memiliki sifat reaktif yang sangat tinggi dan dapat menginaktifkan berbagai macam aktivitas enzim yang diperlukan. Akibatnya proses respirasi redoks pada sel terganggu. Inaktif enzim disebabkan karena adanya penghambatan ion logam terhadap aktivitas protein enzim metallothionin pada konsentrasi tertentu. Konsentrasi ion logam tersebut berkaitan dengan kekuatan ion, dimana kekuatan ion itu sendiri mempengaruhi konformasi atau struktur tiga dimensi dari protein enzim (Richardson dan Hyslop, 1985). Hal inilah yang menyebabkan ion logam Cd bertindak sebagai inhibitor pada aktivitas proteolitik Bacillus sp., karena dengan penambahan ion logam Cd 0,01 \% (100 ppm) ke dalam media padat Mandels yang dimodifikasi dapat menyebabkan fase kematian lebih cepat dibandingkan dengan medium tanpa logam $\mathrm{Cd}$. Menurut Verdian dan Zulaika (2015), bakteri beberapa Bacillus sp. akan mengalami kematian pada konsentrasi cadmium 50 ppm, dan bakteri masih dapat tumbuh pada konsentrasi 30 ppm atau lebih kecil lagi.

Menurut Almeida et al. (2009) Cd, merupakan logam berat yang memiliki efek toksisitas tinggi bagi organisme, bahkan pada tingkat konsentrasi yang rendah. Nies (1999) menambahkan bahwa logam berat dalam sel dapat berikatan dengan gugus sulfuhidril (-SH) asam-asam amino sehingga menyebabkan terhambatnya kinerja enzim yang mempunyai gugus sulfuhidril (-SH) yang memiliki peranan penting dalam proses metabolisme sel. Selain itu, kerja ion-ion fisiologis dapat terganggu oleh adanya logam berat. Senyawa oksianion logam berat apabila tereduksi dalam sel dapat menghasilkan radikal bebas yang akan berikatan dengan DNA sehingga dapat mengakibatkan mutasi.

Paparan medan magnet terhadap ion logam $\mathrm{Cd}$ tidak menyebabkan perubahan pada sifat induktor Cd pada pertumbuhan Bacillus sp. Logam $\mathrm{Cd}$ ketika dipapar medan magnet, tidak mengalami magnetisasi karena $\mathrm{Cd}$ termasuk logam yang bersifat diamagnetik. Diamagnetik adalah sifat suatu bahan yang memiliki resultan medan magnet atomis masing-masing atom atau molekulnya nol, sehingga apabila bahan diamagnetik diberi medan magnet eksternal, maka elektron-elektron dalam atom akan berubah gerakannya sehingga menghasilkan resultan medan magnet atomis yang arahnya berlawanan. Jika ion logam $\mathrm{Cd}$ 
ditambahkan dalam media pertumbuhan bakteri yang melebihi ambang batas, maka akan mempengaruhi aktivitas metaboisme dari bakteri tersebut. Suatu bahan dapat bersifat magnet apabila susunan atom dalam bahan tersebut mempunyai spin elektron yang tidak berpasangan. Dalam bahan diamagnetik hampir semua spin elektron berpasangan, akibatnya bahan diamagnetik tidak dapat menarik garis gaya (Halliday et al., 2013).

Pada perlakuan M-8, pemaparan medan magnet terhadap ion logam $\mathrm{Cu}$ menghasilkan isolat dengan nilai indeks proteolitik (IP) paling tinggi dan lebih tinggi dari nilai IP pada perlakuan M-7, dimana ion logam $\mathrm{Cu}$ yang ditambahkan pada media tidak diberi paparan medan magnet. Hasil ini membuktikan bahwa paparan medan magnet 0,2 $\mathrm{mT}$ pada $\mathrm{CuCl}_{2}$ mampu meningkatkan daya induksi ion $\mathrm{Cu}$ terhadap aktivitas proteolitik Bacillus sp. Hasil penelitian ini sejalan dengan penelitian Arinda et al. (2012) yang menyebutkan bahwa pertumbuhan Bacillus meningkat dengan penambahan logam $\mathrm{Cu}$ sebanyak 30 ppm pada medium pertumbuhan.

Dalam penelitian ini ion logam $\mathrm{Al}, \mathrm{Pb}$, dan $\mathrm{Cu}$ dapat meningkatkan aktivitas kerja suatu enzim disebut sebagai aktivator enzim, sedangkan ion logam yang menghambat aktivitas enzim disebut sebagai inhibitor enzim (Sumardjo, 2006). Ion-ion logam khususnya logam berat sangat mempengaruhi aktivitas enzim. Pada umumnya, logam berat menghambat aktivitas enzim dengan cara merusak sisi aktif enzim tersebut, sehingga enzim tidak dapat berikatan dengan substrat secara tepat. Hal ini menyebabkan penghambatan aktivitas dan degradasi protein enzim (Prasad dan Strzalka, 2002). Namun pada penelitian ini, logam berat $\mathrm{Al}, \mathrm{Pb}$, dan $\mathrm{Cu}$ meningkatkan aktivitas enzim Bacillus sp. Hal tersebut diduga karena Bacillus sp. memiliki kemampuan mengakumulasi logam berat melalui dua mekanisme yaitu mekanisme active uptake dan passive uptake. Bioakumulasi merupakan contoh mekanisme active uptake, yakni melibatkan metabolisme pada sel-sel hidup untuk pertumbuhan atau akumulasi intraseluler logam tersebut. Sedangkan contoh mekanisme passive uptake adalah biosorpsi, yaitu penyerapan logam yang terjadi karena interaksi ion logam dengan per- mukaan sel bakteri. Bakteri memiliki permukaan sel yang bermuatan negatif karena terbentuk dari berbagai struktur anion sedangkan logam berat adalah ion bermuatan positif sehingga dapat terjadi ikatan antara permukaan sel bakteri dan ion logam berat (Satya dan Larasati, 2012). Namun pada penelitian ini belum diketahui mekanisme seperti apa yang terjadi dalam mengakumulasi logam-logam berat tersebut.

Beberapa penelitian menyebutkan bahwa logam berat dapat menurunkan aktivitas pertumbuhan sel bakteri. Seperti penelitian Rakhmawati dan Yulianti (2016) yang membuktikan bahwa isolat bakteri termofilik D13 tidak mampu tumbuh pada media yang mengandung $10 \mathrm{ppm}$ ion logam $\mathrm{Cu}$. Ion-ion logam dengan mudah dapat berikatan dengan gugus sulfhidril protein dan bagian hidroksil dari fosfolipid (Devi dan Prasad, 1999). Ion-ion tersebut juga dapat mengganti ion-ion kalsium pada membran sel (Breckle dan Kahle, 1991). Semua peristiwa di atas dapat meningkatkan permeabilitas membran dan menurunkan aktivitas transport spesifik sehingga merubah homeostasis ionik dan aktivitas enzim untuk metabolisme sel.

Pada penelitian ini, ion-ion logam $\mathrm{Al}, \mathrm{Pb}$, dan $\mathrm{Cu}$ sebelumnya bersifat inhibitor yang menurunkan aktivitas enzim. Akan tetapi, sifat ion-ion logam tersebut berubah menjadi inducer setelah dipapar medan magnet $0,2 \mathrm{mT}$ selama 10 menit pada media cair Mandels yang dimodifikasi, dan menyebabkan aktivitas protease Bacillus sp. meningkat. Berdasarkan hasil tersebut Bacillus sp. yang digunakan dalam penelitian diduga mengalami perubahan ikatan antara ion logam dengan protease, sehingga terjadi peningkatan aktivitas protease. Hasil penelitian ini perlu dikaji lebih lanjut untuk mengetahui kemampuan Bacillus sp. dalam mengakumulasi logam berat $\mathrm{Al}, \mathrm{Pb}$, dan $\mathrm{Cu}$.

Pemaparan medan magnet $0,2 \mathrm{mT}$ pada larutan $\mathrm{Al}, \mathrm{Pb}$, dan $\mathrm{Cu}$ dalam bentuk garam $\mathrm{Al}_{2} \mathrm{Cl}_{3}, \mathrm{PbCl}_{2}$ dan $\mathrm{CuCl}_{2}$ menyebabkan momen dipol molekulmolekul tersebut menjadi terarah, sehingga kelarutannya menjadi lebih besar dibandingkan dengan kelarutan protein. Kondisi ini menyebabkan ion garam akan menarik molekul air dari protein enzim. Menurut Whitaker (1996), 
logam dalam bentuk garam organik di dalam media dapat menyebabkan kestabilan enzim dengan cara menetralkan kelebihan muatan elektrostatik molekul enzim sehingga konformasi enzim dapat dipertahankan. Pendapat ini sejalan dengan hasil penelitian yang dilakukan oleh Sumardi et al. (2018a) yang membuktikan bahwa dengan adanya penambahan ion $\mathrm{Na}^{+}$dalam bentuk garam $\mathrm{NaCl}$ pada mediakultur yang dipapar medan magnet 0,2 mT selama 10 menit mampu meningkatkan aktivitas protease Bacillus sp. Sumardi et al. (2018b) menambahkan bahwa ion logam Fe dalam bentuk garam $\mathrm{FeCl}_{3}$ pada konsentrasi $0,01 \%$ yang telah dipapar medan magnet meningkatkan aktivitas enzim protease sebesar 0,06 U/ml dibandingkan sebelum dipapar medan magnet yaitu $0,005 \mathrm{U} / \mathrm{mL}$.

Pemberian medan magnet juga berpengaruh langsung terhadap aktivitas metabolisme sel. Seperti hasil penelitian yang telah dilakukan oleh Hernawati et al. (2016) yang membuktikan bahwa pemaparan medan magnet pada medium pertumbuhan menyebabkan respon aktivitas relatif enzim selulase menjadi berfluktuasi yang cenderung meningkat, disebabkan adanya pengaruh sifat-sifat kimia dari unsur-unsur yang terdapat dalam medium kultur. Unsur-unsur kimia pada medium kultur tersebut juga diduga memiliki elektronegativitas, energi ionisasi, dan afinitas elektron yang berbeda sehingga menyebabkan aktivitas enzim selulase menjadi kurang stabil.

Secara umum medan magnet mempengaruhi arah migrasi dan mengubah laju pertumbuhan, mengubah aliran ionik yang melalui membran sehingga mengakibatkan perubahan kecepatan reproduksi sel (Sudarti et al., 2014). Kekuatan medan magnet yang diberikan pada bakteri harus tepat karena kuat medan magnet yang terlalu besar justru akan menghambat pertumbuhan bakteri. Jika kuat medan magnet yang diberikan terlalu tinggi dan dalam pemaparan waktu yang tidak tepat akan menyebabkan metabolisme yang tidak menguntungkan bagi pertumbuhan sel atau menyebabkan perubahan pada struktur membran. Beberapa peneliti menduga bahwa tempat reaksi medan magnet dalam sistem biologi adalah plasma elektromagnetik membran (Setyasih et al., 2013).
Peningkatan ukuran panjang sel bakteri yang paling tinggi diperoleh dari penambahan ion logam Al. Penambahan ion logam Al tanpa paparan medan magnet (MAl-0) yaitu $2.947 \mu$ m meningkat menjadi $3.404 \mu \mathrm{m}$ pada perlakuan penambahan ion logam Al yang dipapar medan magnet (MAl-1). Hasil ini diduga penambahan ion logam Al yang diberi paparan medan magnet memacu metabolisme sel Bacillus sp. yang mengakibatkan terjadinya peningkatan ukuran panjang sel bakteri. Ion-ion logam seperti ion logam Al dengan mudah dapat berikatan dengan gugus sulfhidril protein dan bagian hidroksil dari fosfolipid (Devi dan Prasad 1999). Ion-ion tersebut juga dapat mengganti ionion kalsium pada membran sel (Breckle dan Kahle 1991). Semua peristiwa di atas dapat meningkatkan permeabilitas membran dan aktivitas enzim untuk metabolisme sel.

Ion logam Al pada organisme tidak termasuk kedalam unsur hara essensial. Keberadaan unsur ion logam Al pada tumbuhan justru menghambat pertumbuhan akar. Proklamasiningsih et al. (2012) membuktikan bahwa pemberian ion logam $\mathrm{Al}$ dalam bentuk garam pada media tanam akar kedelai menurunkan panjang akar kedelai dari $398,33 \mathrm{~cm}$ (perlakuan pemberian ion logam $\mathrm{Al}$ ) menjadi 398,33 cm pada perlakuan kontrol (tanpa pemberian ion logam Al). Penurunan panjang akar kedelai disebabkan karena terganggunya proses metabolisme di dalam sel-sel ujung akar yang mengakibatkan terjadinya penghambatan pemanjangan akar dan berubahnya morfologi sistem perakaran. Horst et al. (1999) menambahkan bahwa mekanisme penurunan panjang akar oleh Al disebabkan karena $\mathrm{Al}$ menghambat jalur apoplas pada dinding sel dan membran plasma yang dapat mengganggu proses masuknya unsur hara. Jalur apoplas adalah jalur masuknya unsur hara melalui ruang antar sel, kemudian menembus membran plasma yang akhirnya masuk ke dalam sel (Kvesitadze et al., 2006).

Peningkatan ukuran relatif sel dapat terjadi setelah bakteri tersebut ditumbuhkan pada media yang mengandung ion logam diberi paparan medan magnet. Hal tersebut sejalan dengan pernyataan Setyasih et al. (2013) yang mengatakan bahwa 
medan magnet dapat mengubah karakteristik membran sel, mempengaruhi reproduksi sel, menyebabkan perubahan pada metabolisme sel serta mempengaruhi karakteristik pertumbuhan. Menurut Talley dan Sleeper (1997), logam berat meski tidak secara essensial dibutuhkan tetapi dapat diakumulasi dan dimanfaatkan oleh mikroorganisme melalui berbagai mekanisme, seperti pertukaran ion pada dinding sel, reaksi pembentukan kompleks pada dinding sel, reaksi pembentukan kompleks intraseluler dan ekstraseluler dan biomassanya secara aktif dapat mengadsorpsi logam dalam bentuk gugus-gugus ionik pada permukaan sel dan lapisan polisakarida pada bakteri.

Berbeda dengan peran logam $\mathrm{Al}$ pada tumbuhan (Proklamasiningsih et al., 2012), dalam penelitian dengan bakteri Bacillus sp. menunjukkan bahwa pemberian logam Al pada media pertumbuhan bakteri dapat meningkatkan ukuran panjang sel bakteri dibandingkan dengan media tanpa penambahan logam Al (Gambar 5). Pada tumbuhan, senyawa yang tidak dibutuhkan dikeluarkan dari sel dan disimpan di dalam dinding sel, sedangkan pada mikroba senyawa Al tidak masuk ke dalam sel tapi terakumulasi pada dinding sel. Ion logam Al diduga berperan dalam mempengaruhi kondisi kimia media, $\mathrm{pH}$ dan keseimbangan ion yang membantu proses metabolisme sel pada bakteri yang mengakibatkan terjadinya peningkatan ukuran panjang sel bakteri. Penelitian yang telah dilakukan oleh Gaafar et al. (2006) menjelaskan bahwa paparan medan magnet $2 \mathrm{mT}$ selama 16 jam dapat meningkatkan ukuran panjang sel pada Escherichia coli.

Dalam penelitian ini, logam Al yang dipapar medan magnet dapat meningkatkan ukuran panjang sel bakteri Bacillus sp. sebesar $20 \%$ dibandingkan dengan tanpa paparan medan magnet dan berbanding lurus dengan aktivitas proteolitik yang dihasilkan Bacillus sp (Gambar 4). Hal ini diduga karena adanya interaksi positif antara ion logam yang dipapar medan magnet dengan sel bakteri Bacillus sp. Ion logam berat yang pada umumnya merugikan karena bersifat toksik, namun pada penelitian ini menguntungkan Bacillus sp. Diduga terjadi proses mekanisme biosorpsi yang berhubungan dengan eksopolisakarida pada dinding sel bakteri yang berfungsi sebagai pengkelat logam berat di permukaan sel, sehingga ion logam-logam berat seperti $\mathrm{Al}, \mathrm{Pb}$, dan $\mathrm{Cu}$ tidak meracuni sel bakteri. Molekul kompleks pada dinding sel bakteri terdiri dari peptidoglikan yang tersusun oleh molekuk-molekul yang lebih sederhana antara lain fosforil, karboksil, dan asam amino yang mempunyai muatan negatif. Muatan negatif akan berinteraksi dengan ion atau molekul yang bermuatan positif di lingkungan luarnya sehingga berbentuk ikatan ligan. Ion logam Al bermuatan positif, sehingga secara elektrostatik akan terikat pada permukaan sel (Langley dan Baveridge, 1999). Interaksi antara ion logam dan dinding sel bakteri Gram positif Bacillus sp. menunjukkan adanya peranan gugus karboksil pada peptidoglikan dan gugus fosforil pada polimer sekunder asam teikoat dan teikuronat (Lloyd, 2002).

\section{KESIMPULAN}

Pada medium padat, indeks proteolitik Bacillus sp. terbesar pada medium yang mengandung $\mathrm{CuCl}_{2}$ dipapar medan magnet $0,2 \mathrm{mT}$ selama 10 menit $(4,33)$. Pada medium yang mengandung $\mathrm{CdCl}_{2}$,, $01 \%$ bakteri Bacillus sp tidak tumbuh. Pada produksi enzim di medium cair, aktivitas protease tertinggi dihasilkan pada medium yang mengandung larutan $\mathrm{AlCl}_{3}$ dipapar medan magnet $(0,140 \mathrm{U} / \mathrm{ml})$. Hasil pengamatan SEM juga membuktikan bahwa pemberian logam $\mathrm{AlCl}_{3}$ meningkatkan panjang sel hingga 2,38 kali dibandingkan kontrol.

\section{UCAPAN TERIMA KASIH}

Riset penulis dibiayai oleh Hibah Penelitian Pascasarjana Universitas Lampung dengan kontrak No: 809/UN26.21/PP/2017, tanggal 27 Juli 2017

\section{DAFTAR PUSTAKA}

Almeida, J.A., Barreto, R.E., Novelli, L.B., Castro, F.J. and Moron, S.E., 2009. Oxidative Stress Biomarkers and Agressive Behavior in Fish Exsposed to Aquatic Cadmium Contamination. Neotropical Ichtyology, 7, pp. 103-108.

Arinda, T., Shovitri, M. and Zulaikha, E., 2012. Resistensi Bakteri Bacillus Terhadap Logam Berat. Scientific Conference of Environmental Technology IX-2012. ITS. Surabaya.

Baehaki, A., Rinto, dan Budiman, A., 2011. Isolasi dan 
karakterisasi protease dari bakteri tanah rawa Inderalaya, Sumatera Selatan. Jurnal Teknologi dan Industri Pangan, 22(1), pp. 40-45.

Badriyah, B.I. dan Ardyati, T., 2013. Deteksi aktivitas proteolitik isolat bakteri asal ampas tahu pada substrat bekatul. Jurnal Biotropika, 1(3), pp. 109113.

Bergmeyer, H.V. and Grassl. 1983. Menthods of Enzymatic Analysis. Vol II. Verleg Chemi. Weinhein.

Breckle, S.W. and Kahle, H., 1991. Ecological geobotany/ autecology and ecotoxicology. In: Behnke HD, editor. Progress in botany. vol. 52. Berlin/Heidelberg: Springer-Verlag; pp. 391-406.

Devi, S.R. and Prasad, M.N.V., 1999. Membrane lipid alterations in heavy metal exposed plants. In: Prasad $\mathrm{MNV}$, Hagemeyer J, editors. Heavy metal stress in plants: from molecules to ecosystems. Berlin: Springer-Verlag; pp. 99-116.

Erika, R., Agustrina, Sumardi, dan Mulyono. 2016. Optimasi media produksi xilanase dari Bacillus sp. Jurnal selulosa. 6(1), pp. 19-26.

Gaafar, El-Sayed, A., Hanafy, M.S., Tohamy, E.Y. dan Ibrahim, M.H., 2006. Stimulation and control of E.coli by using an extremely low frequency magnetic field. Journal Biophys, 16(4), pp. 283-296.

Halliday, D., Resnick, R. and Walker, J., 2013. Fundamentals of Physics Extended, 10th Edition. Willey. p. 1448

Hernawati, W., Sumardi, Agustrina, R. dan Yulianto, H., 2016. Pengaruh Pemaparan Medan Magnet Pada Media Mandel yang Dimodifikasi terhadap Pertumbuhan dan Aktivitas Enzim Selulase Bacillus sp. Jurnal Penelitian Pertanian Terapan, 16(2), pp. 76-84.

Horst, W.J., Schmohl, N., Kollmeier, M., Baluska, F. and Sivaguru, M., 1999. Does aluminium affect roo growth of maize through interaction with the cell wall-plasma membrane-cytoskeleton continuum? Plant and Soil, 215, pp.163-174.

Jonak, C., Nakagami, H. and Hirt, H., 2004. Heavy Metal Stress. Activation MitogenActivated Protein Kinase Pathways by Copper and Cadmium. Plant Physiology, 136, pp. 3276-3283.

Kvesitadze, G, Khatisashvili, G., Sadunishvili, T. and Ramsden, J.J., 2006. Biochemical Mechanisms of Detoxification in Higher Plants. Springer-Verlag Berlin Heidelberg Printed in Germany.

Langley, S. and Baveridge, T.J., 1999. Effect of O-side chine Lipopolysaccaride Chemistry on Metal Binding. Applied and Environmental Microbiology, 65, pp $489-498$.

Lloyd, J.R., 2002. Bioremediation of metals, the application of microorganisms that make and break minerals. Microbial Today, 29, pp.67-69.

Mandels, M. and Reese, E.T., 1957.Induction of cellulose in Trichoderma viride as influenced by carbon source and metals. Journal of Bacteriology, 73(2), 269-278.

Mahdiyah, D., 2015. Isolasi Bakteri dari Tanah Gambu Penghasil Enzim Protease. Jurnal Pharmascience, 2 (2), pp.71-79.

Nies, D.H., 1999. Microbial heavy metal resistance: molecular biology and utilisation for biotechnological processes. Applied Microbiology and Biotechnology, 51, pp.730-750.

Prasad, M.N.V. and Strzalka, K., 2002. Physiology and biochemistry of metal toxicity and tolerance in plants. Dordrecht, Kluwer Academic Publishers, p. 432

Rakhmawati, A. dan Yulianti, E., 2016. Resisten Bakteri Termofilik Pasca Erupsi Merapi Terhadap Logam Berat. Prosiding Seminar Nasional LPPM, Universitas Negeri Yogyakarta.

Richardson, T. and Hyslop, D.B., 1985. Enzyme, Mac Kerel Bekker, Inc. New York.

Rosliana, P., 2009. Isolasi Bakteri dan Uji Aktivitas Protease
Termofilik dari Sumber Air Panas Sipoholon Tapanuli Utara Sumatera Utara. Tesis. Universitas Sumatera Utara.

Proklamasiningsih, E., Prijambada, Rachmawati, I.D. dan Sancayaningsih, R.P., 2012. Pengaruh Pemberian Garam Alumunium (Al) Terhadap Serapan Al dan Pertumbuhan Akar Kedelai pada Media Tanam Masam. Bionaturna-Jurnal ilmu-ilmu Hayati dan Fisik, 14(2), pp.107-114

Said, M.I. dan Likadja, J.C., 2012. Isolasi dan Identifikas Bakteri yang Berpotensi sebagai Penghasil Enzim Protease pada Industri Penyamakan Kulit Pt. Adh Satria Abadi (Asa), Yogyakarta. Makalah Ilmiah. Fakultas Peternakan, Universitas Hasanuddin. Makassar.

Satya, A. dan Larasati. 2012. Kemampuan Isolat Bakteri dari Sedimen Situ sebagai Aquatic Bioremoval Agent Ion Logam Timbal $(\mathrm{Pb})$. Prosiding Seminar Nasional VI Tahun 2012

Setyasih, N., Agustrina, R., Handayani, T.T. dan Ernawiati., E., 2013. Pengaruh Medan Magnet 0,3 mT terhadap Stomata Daun Tanaman Tomat (Lycopersicum esculentum Mill.). Prosiding Semirata FMIPA Universitas Lampung.

Singh, R., Srivastava, M., Rohatgi, B., Kar, A. and Shukla, A. 2017. microwave assisted chemical pretreatmen method for bio-ethanol production from rice straw. Asian Journal of Chemistry, 29(15), pp. 943-950. https://doi.org/10.14233/ajchem.2017.20190

Soeka, Y.S. dan Sulistiani. 2014. Karakterisasi Protease Bacillus Subtilis A1 Inacc B398 yang Diisolasi Dari Terasi Samarinda. Berita Biologi, 13(2), pp. 203-212.

Sudarti, Nurhayati, Ruriani, E. and Hersa, V.T., 2014 Prevalence of Salmonella Typhimurium on GadoGado Seasoning by Treatment of Extremely Low Frequency (ELF) Magnetic Field.Artikel-ELFSalmonella. Jember University.

Sumardi, C.N., Ekowati, dan Handayani, D., 2010. Isolasi Bacillus Penghasil Selulase dari Saluran Pencernaan Ayam Kampung. Jurnal Sains Mipa, 16(1), 62-68.

Sumardi, R. Agustrina, Irawan, B. dan Pratiwi, A., 2018a. The Effect of Magnetic Field Exposure on Medium to Protease Production by Bacillus sp. BIOVALENTIA: Biological Research Journal, 4(2), 2477-1392.

Sumardi, Agustrina, R., Irawan, B. dan Selviana, I., 2018 b. Pengaruh paparan medan magnet pada ion logam $\mathrm{Fe}$ dan $\mathrm{Zn}$ dalam media pertumbuhan thdp produksi protease Bacillus sp. Jurnal ilmu lingkungan - PS Ilmu Lingkungan UNDIP, 6(2), pp. 173-177.

Sumardi, Agustrina, R., Ekowati, C.N., Putra, R.O. and Hartono, M., 2019. The effect of magnetic field on antibiotic inhibition for Escherichia coli and Bacillus sp.

Sumardjo, D., 2006, Pengantar Kimia, Penerbit Buku Kedokteran EGC, Jakarta.

Talley, J.W. and Sleeper, P.M., 1997. Roadblocks to the Implementation of Biotreatment Strategies, dalam Rakes K.B dan Mark E.z (ed). Bioremediation of Surface and Subsurface Contamination. The New York Academy of Science. New York.

Verdian T. dan Zulaika, E., 2015. Resistensi dan Viabilitas Bacillus S1, SS19 dan DA11 pada Medium yang Terpapar Logam Kadmium (Cd). Jurnal sains dan seni ITS. 4(2), pp. 88-90.

Whitaker, J.R., 1996. Enzyme in Food Chemistry: Third Edition. Marcel Dekker Inc.New York.

Yusufa, Mohammad, H., Masdiana, C., Padaga, Dyah, A. dan Octavianie. 2012. Identifikasi dan studi aktivitas protease Bacillus sp asal limbah cair rumah potong ayam tradisional sebagai kandidat penghasil biodeterjen. Universitas Brawijaya.

Zeiss, C., 2019. Company of Carl Zeiss Microscopy Gmbh.0774 Jena. Germany. www.zeiss.com/evo 